\title{
Estudio de la interfase en los hormigones reforzados con fibras
}

\author{
Interface study of fiber \\ reinforced concrete
}

ANTONIA PACIOS, Dr. Arquitecto (IETCC-CSIC)

MANUEL FERNÁNDEZ CÁNOVAS, Dr. Ingeniero de Construcción (ETSCCP-UPM)

Fecha de recepción: 21-V-97

Fecha de aceptación: 3-VII-97

MADRID/ESPAÑA

\begin{abstract}
RESUMEN
En un material compuesto que utiliza fibras como refuerzo, la rotura de la matriz se produce conjuntamente con la separación de la fibra de la matriz, por lo que el comportamiento mecánico de la interfase describe hasta que punto las fibras pueden trabajar como estabilizadores en el proceso de fisuración. La interfase es el medio que pone en carga a la fibra y, por ello, la resistencia mecánica de la interfase y de la fibra son dos parámetros importantes a considerar para caracterizar el comportamiento general del composite.
\end{abstract}

Este trabajo investiga el efecto de la variación del tipo de fibra, geometria y dimensión de las mismas y las modificaciones de la matriz y la velocidad de desplazamiento en el comportamiento de la interfase. Se ha puesto a punto una técnica experimental que permita utilizar la misma configuración del ensayo de pull-out en una prensa universal quasi-estática y en un péndulo Charpy.

Si mejoramos la matriz con la incorporación de una adición mineral se consiguen aumentar las resistencias hasta en un 100\%. Al mismo tiempo se observa que combinando las dos acciones, una matriz con humo de silice y una fibra de acero ondulada a lo largo de la generatriz se puede modificar el tipo de fallo, produciéndose la rotura de la fibra y, por lo tanto, con menor tenacidad. Con el aumento de la inclinación de la fibra y la velocidad de carga también se modifican las fuerzas de adherencia.

\begin{abstract}
SUMMARY
In a composite material that uses fibers as reinforcement, the breakage of the matrix is produced jointly with the separation of the fiber from the matrix. The mechanical behavior of the interface describes how fibers can work stabilizing the cracking process. The interface is the medium that puts the fiber on load, being the mechanical behavior of the interface and the strength of the fiber two important parameters to consider to characterize the general behavior of the composite.
\end{abstract}

The present work studies the effect of several parameters on the behavior of the interface. Those parameters are the type of fiber, its geometry and dimension and the modified matrix and loading rate. An experimental technique was designed to allow testing the same set-up for pull-out tests in a quasistatic machine and Charpy pendulum.

Modifications of the matrix by adding a mineral admixture improve the behavior of the interface as much as a $100 \%$. It has been observed that combining the two actions, an improved matrix with crimped fibers, the type of failure can be modified. In this new type of failure, the fiber breaks consequently toughness decreases. Other parameters, as the loading rate and inclination of the fiber also affect the behavior of the interface. 


\section{INTRODUCCIÓN}

Los materiales compuestos con matriz de cemento se comportan de manera muy diferente a como lo hacen los compuestos de matriz orgánica. Las fibras en los materiales de matriz orgánica tienen una menor deformación en la fractura y se comportan como lugares de iniciación del fallo mientras la matriz se deforma plásticamente y permanece dúctil. En los materiales compuestos con matriz de cemento la matriz es la primera en fallar, pues tiene la menor deformación en la fractura. Con este tipo de matriz o matrices cerámicas una buena adherencia entre las fibras y la matriz no es necesariamente deseable. La investigación demuestra que la resistencia mecánica y la tenacidad del material compuesto aumentan significativamente cuando la adherencia falla y se produce el arrancamiento de la fibra.

En los hormigones reforzados con fibras el comportamiento de la interfase entre la fibra y la matriz tiene una gran importancia en el comportamiento mecánico final del material compuesto. Puesto que las fibras se introducen, principalmente, para mejorar la tenacidad y resistencia de las matrices frágiles, la capacidad de las fibras de interaccionar con el mecanismo que gobierna la ductilidad es importante. El aumento de la tenacidad es el resultado de la operación de varios mecanismos de absorción de energía, controlados por la resistencia de la interfase entre la fibra y la matriz. La rotura de la interfase, el desvío de las grietas y la extracción de las fibras contribuyen a aumentar la tenacidad y dependen, básicamente, de una débil adhesión en la interfase entre las fibras y la matriz $(1,2)$.

Experimentalmente, se ha abordado el problema de la medida de la resistencia de la interfase. Se han utilizado para su caracterización ensayos de compresión en una probeta entallada, ensayos de flexión y ensayos de pull-out (extracción) y push-out (introducción) de las fibras (3). Cada uno de ellos presenta una serie de ventajas y desventajas. El ensayo de compresión, por ejemplo, requiere técnicas acústicas de detección de fallos o inspección visual, el de flexión no proporciona una medida real de la resistencia de la interfase y es, de entre todos, el ensayo de extracción de fibras el más representativo y, por lo tanto, el más desarrollado.

El ensayo de extracción de fibras es de gran interés para un hormigón reforzado con fibras porque simula la configuración de una fibra rodeada por una grieta en la matriz. En este ensayo se embebe una porción de fibra en la matriz y se aplica una fuerza de tracción para extraerla. Para longitudes embebidas mayores que un cierto valor crítico la fibra se fracturará. Para

\section{INTRODUCTION}

The cementitious matrix composites behave in a different way from those with an organic matrix. The fibers in composites with organic matrix have a smaller deformation in the fracture and behave as cracking initiation place while the matrix has a plastic strain and stays ductile. In the cementitious matrix composite it is the matrix the one that breaks first since it has the smaller deformation in the fracture. With this type of matrix, or ceramic matrix, a good adherence between the fibers and the matrix is not always desirable. Research shows that mechanical strength and toughness of the composite increase significantly when the adherence fails and pull-out of the fiber.

In the fiber reinforced concrete the behavior of the interface between fiber and matrix has a great importance in the final mechanical behavior of the composite. Since fibers are mainly introduced to improve toughness and strength of the brittle matrix the fibers, is the interactioning capacity with the mechanism that governs the toughness very important. The increase in toughness is the result of several mechanisms of energy absorption controlled by the behavior of the interface between the fiber and the matrix. The failure of the interface, the crack deviation and the pull-out of the fibers contribute to increase the toughness. It depends basically on a weak bonding between the fibers and the matrix. $(1,2)$

The measurement of the interface strength has been experimentally approached. For its characterization several configuration have been used: compression test in guitar-shaped specimen, flexion, pull-out and pushout test of fibers (3). Each one presents a series of advantages and disadvantages. The compression test, for example, requires acoustic techniques for detection of failure or visual inspection of the specimen, the flexion test does not provide a real measurement of the interface strength, so the pull-out test is the most representative and most developed one.

The pull-out test is of great interest for fiber reinforced concrete because it simulates the configuration of a fiber surrounded by a crack in the matrix. In this test a part of the fiber is embedded on the matrix and a tension force is applied to pull the fiber out. For embedded lengths longer than a critical value the fiber will break. For lengths smaller than the critical length 
longitudes menores de la longitud crítica la fibra se arrancará y la resistencia a cortante de la interfase se puede calcular por un sencillo equilibrio de fuerzas. Durante el ensayo se registra la evolución de la carga frente al desplazamiento.

Actualmente, la investigación en los materiales compuestos con matriz de cemento avanza en dos direcciones: la selección de la adecuada combinación de la matriz y del material de refuerzo junto con el mejor entendimiento del fenómeno de separación entre las fibras y la matriz (4) y las mejoras de las técnicas de producción de los compuestos.

Se han realizado diversos trabajos, estudiando el efecto de las distintas variables en el compuesto. Banthia et al. (5) estudian el efecto de la extracción de una fibra de acero con distinta geometría. Ouyang et al. (6) y Pacios et al. (7) modelizan el fenómeno de la velocidad de carga e inclinación de la fibra. Vittuari (8) analiza el comportamiento de las fibras de nylon, tanto rectas como inclinadas, a distintas velocidades de carga. Li et al. (9) analizan la adherencia de las fibras de polipropileno y nylon en una matiz de cemento.

\section{DESCRIPCIÓN DEL EQUIPO UTILIZADO}

\subsection{Dispositivo experimental de la máquina quasi-estática.}

Los ensayos de extracción de las fibras a velocidades lentas se realizaron en una prensa universal con control de bucle cerrado. La Fig. 1 muestra la configuración empleada y el diagrama esquemático del sistema. Debe the fiber will be pulled-out and the shear strength can be calculated by simple forces equilibrium. During the test the evolution of the load and the displacement are registered.

At the present time, research on composite materials with cementitious matrix advances in two directions: the selection of the adequate combination of matrix and reinforcement fibers together with a better understanding of the debonding between fibers and matrix (4) and the improvements of production techniques of the composites.

Several projects studying the effect of the different variable in the composite have been accomplished. Banthia et al. (5) study the effect of geometry on the pull-out of a steel fiber from a matrix. Ouyang et al. (6) and Pacios et al. (7) propose a model to describe the loading rate and inclination of the fiber effect. Vittuari (8) studies the nylon fiber behavior at different rates of loading and inclinations. Li et al. (9) study the polypropylene and nylon fiber bonding to a cementitious matrix.

\section{DESCRIPTION OF SET-UP EQUIPMENT}

\subsection{Quasi-static machine configuration}

The pull-out of fibers from a cementitious matrix for quasi-static rates was conducted using a close loop control machine. A scheme of this configuration can be found in Fig. 1. The fibers undergo a tension force

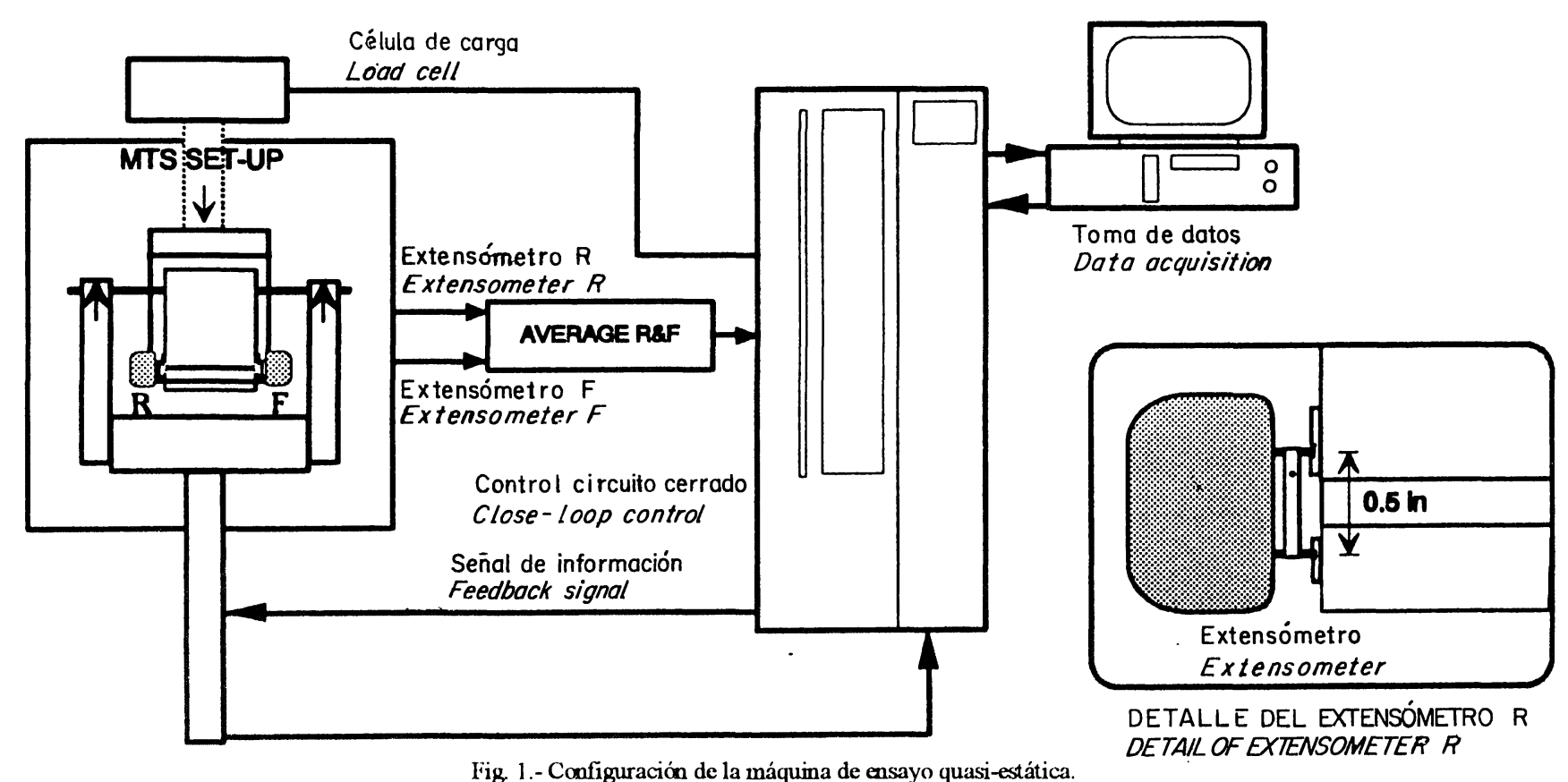

Fig. 1.- Schematic of quasi-static machine configuration. 
notarse que, aunque el movimiento del pistón es de compresión, las fibras están sometidas a un esfuerzo de tracción.

Las galgas y el equipo utilizado en las mediciones son:

- célula de carga de $4.450 \mathrm{~N}$ (empleada la calibración al $10 \%)$.

- dos extensómetros de 1,9 $\mathrm{mm}$ de recorrido y ancho de banda de $12,7 \mathrm{~mm}$.

- analizador de señales eléctricas.

Es especialmente importante la medida de las deformaciones antes de la carga máxima; cuanto mayor sea el área sobre la que se está midiendo, más deformaciones ajenas al fenómeno de la extracción de la fibra estarán incluidas. Podemos comparar, por ejemplo, el desplazamiento realizado por el pistón de la máquina con el registrado por los sensores de desplazamiento (10).

Puesto que los ensayos realizados con la configuración anterior eran poco fiables, dado el rango en el que se obtenían los valores y el elevado ruido de la señal, los ensayos de las probetas con fibras de nylon se han tenido que realizar en una prensa distinta. Se ha modificado la capacidad de la célula de carga a una de $445 \mathrm{~N}$, no llegando a sobrepasar el $80 \%$ de la capacidad de la misma.

Asimismo, se modificó la configuración de la sujeción de la probeta para realizar el ensayo en tracción, no en compresión como para las fibras metálicas. Se registraron las señales de fuerza y de los dos desplazamientos laterales. No se ha podido utilizar la señal media de los dos desplazamientos como controlador del ensayo, modificando el control de ensayo a control de desplazamiento. Los extensómetros utilizados tienen un ancho de banda de $25,4 \mathrm{~mm}$ y un recorrido de $\pm 50 \%$.

\subsection{Dispositivo experimental del péndulo de Charpy}

En este estudio se utilizó un péndulo Charpy convencional, Tinius Olsen Model 64, que se modificó e instrumentó para facilitar el ensayo a realizar. En su instrumentación se emplearon tres células de carga dinámicas de rangos $4.450 \mathrm{~N}$, de tipo anillo y una célula de carga de impacto de $22.250 \mathrm{~N}$. Dos galgas multiuso de impedancia variable se emplearon para medir el desplazamiento entre la fibra y la matriz. Se registró la aceleración del conjunto durante el impacto. Detalles de la configuración del montaje para el ensayo de impacto se muestran en la Fig. 2. Detallada even thought the actuator moves in the compression direction.

The gages and equipment used to the measurement are:

- load cell of $4.450 N$ capacity (used in a 10\% range calibration).

- two extensometers with a range of $1.9 \mathrm{~mm}$ and a gage length of $12.7 \mathrm{~mm}$.

- electrical signal averaging box.

It is especially important the strain measurement prior to the maximum load; the bigger the gage length the more erroneous strains will be included. The actuator movement compared to the displacement measured by the extensometers shows the phenomenon (10).

Since the results obtained with the previously described configuration were not too accurate due to the signals noise and the small range of loads, the nylon fibers pull-out tests were performed in a different machine. The load cell capacity was changed to $445 \mathrm{~N}$, never reaching $80 \%$ of the full capacity.

The configuration of the specimen grip was modified to perform the test in tension not in compression. Force signals and the two lateral displacements were registered. It was not possible to use the average signal of the two displacements as feedback control signal for the test, so actuator displacement control was used. The extensometers used have a gage length of $25.4 \mathrm{~mm}$ and a range of $\pm 50 \%$

\subsection{Experimental device of the Charpy pendulum}

In this study, a conventional Charpy pendulum, Tinius Olsen Model 64, was modified and instrumented to facilitate the test. Three dynamic load cells were used to instrument the striker and support of the pendulum, two ring load cells of $4.450 \mathrm{~N}$ capacity and an impact load cell of $22.250 \mathrm{~N}$ capacity. Two non-contact gages, multi purpose variable impedance gages were used to measure the slip between fibers and the matrix. Acceleration of the system during impact was also registered. A detail of the test set-up is shown in Fig. 2. 

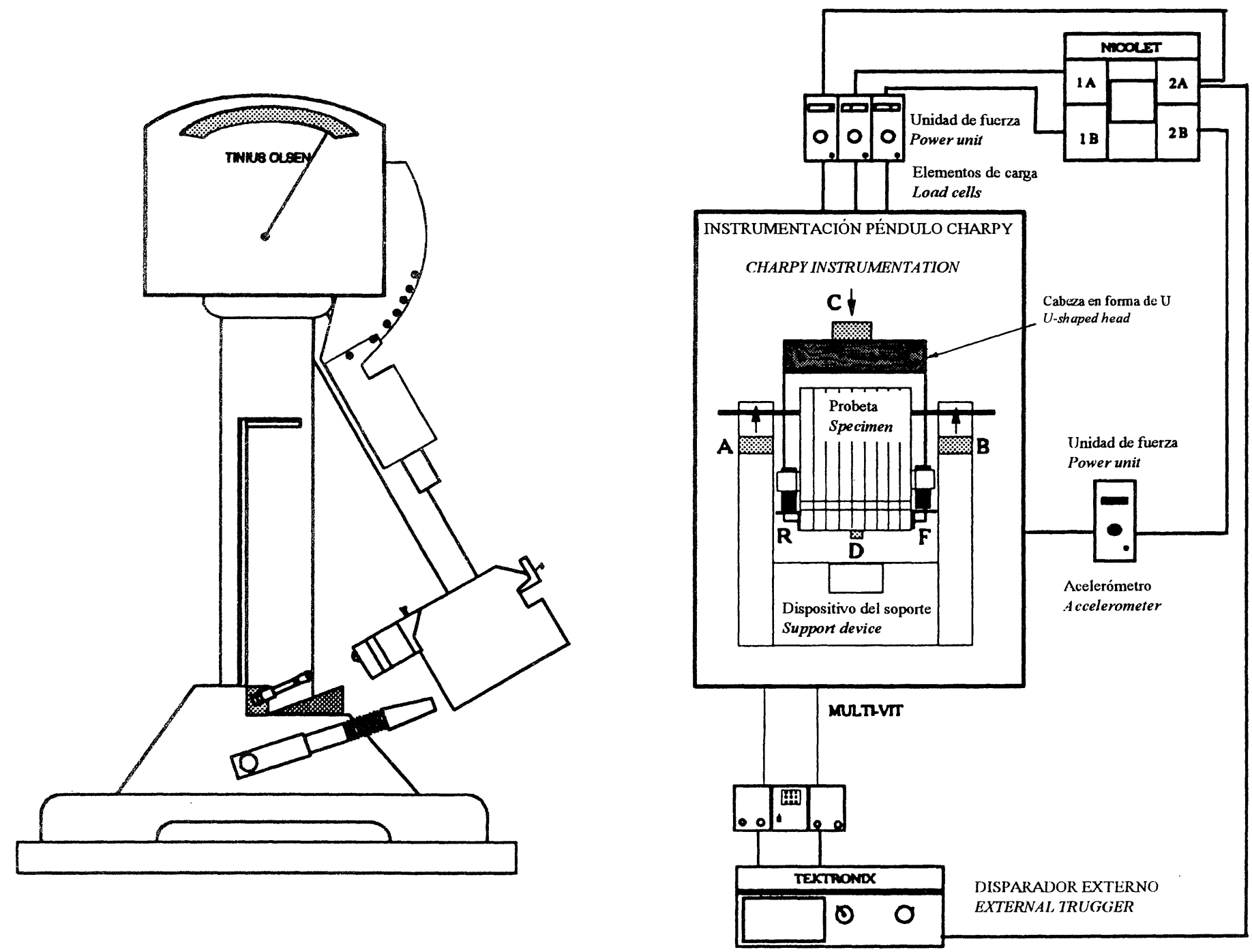

Fig. 2.- Configuración del péndulo Charpy.

Fig. 2.- Schematic of Charpy configuration.

descripción del sistema se puede encontrar en Pacios et al. (7).

Se ha utilizado la misma configuración tanto para los ensayos de extracción de fibras metálicas como de nylon. En el caso particular de las fibras de nylon, las señales obtenidas por las fuerzas laterales presentaban una oscilación parasita (una vez sobrepasada la carga máxima) que puede responder a la respuesta de resonancia del péndulo en el choque. En general, un choque o impacto cubre una larga gama de frecuencias. Es bastante probable que la frecuencia propia del péndulo de Charpy se encuentre en este dominio de frecuencias. Se ha filtrado la señal de 5 a $10 \mathrm{kHz}$, siendo la frecuencia de adquisición del orden de $100 \mathrm{kHz}$ (entre 2.000 y 4.000 puntos para la adquisición total de $40 \mathrm{~ms}$ ).

\subsection{Ensayos de compresión}

Por cada amasada se realizaron tres probetas cilindricas de $5 \times 10 \mathrm{~cm}$, para evaluar la calidad de la matriz. Se ha
A further system description can be found in Pacios et al. (7).

For the nylon and steel fibers pull-out test, the same configuration was used. A parasite signal in the lateral load cells was present in the nylon fibers pull-out test, once maximum load was reached (probably due to resonance response of the pendulum during impact). Generally, in an impact a large variety of frequencies are involved. It is quite probable the (harpy frequency is in that frequency domain. Signals were filtered 5 to $10 \mathrm{kHz}$, from the acquisition frequency of $100 \mathrm{kHz}$ (2.000 to 4.000 points for a $40 \mathrm{~ms}$ event).

\subsection{Compression test}

For each batch, in addition to the pull-out specimens, three cylindrical specimens of $5 \times 10 \mathrm{~cm}$ were cast. That 
utilizado una prensa hidráulica para su ensayo. La carga se ha aplicado a una velocidad de $0,5 \mathrm{~N} / \mathrm{s}$. Se han registrado las deformaciones a lo largo de dos generatrices utilizando extensómetros MTS con un ancho de banda de $2 \mathrm{~cm}$.

La dispersión obtenida para las probetas sin humo de sílice ha sido mayor que para las obtenidas con la incorporación de éstas. Algunos valores se salen del intervalo de confianza.

\section{PROGRAMA EXPERIMENTAL}

Para la preparación de las probetas se utilizó un molde diseñado para realizar series de 6 probetas $y$, con ello, asegurar la homogeneidad de las mismas en cada serie. El molde empleado facilita un control sobre la alineación de las fibras y permite modificar la separación e inclinación de las fibras (6). Se ha tenido especial cuidado en mejorar la adherencia de la fibra en la mitad mayor de la probeta y así garantizar que la separación fibra-matriz se produzca en aquella mitad en que la longitud embebida es menor. Las características de los materiales empleados se encuentran en la Tabla I. allows evaluating the control of quality of the matrix. A hydraulic press has been used. The load has been applied to a speed of $0.5 \mathrm{~N} / \mathrm{s}$. Strain along two opposite longitudinal lines have been registered using MTS extensometers with a gage length of $2 \mathrm{~cm}$.

The dispersion obtained for specimens without silica fime has been higher than for the obtained with its incorporation. Some values are left out the confidence interval.

\section{EXPERIMENTAL PROGRAM}

For the specimens preparation a mold designed to cast series of 6 specimens and thus assuring specimens homogeneity was used. The mold facilitates a control over the alignment of the fibers and allows to modify the separation and inclination of fibers. (6). Special care was taken into improve the adherence between fiber and matrix in the longer pari of the matrix. In this way the fiber embedded in the shorter part of the matrix is pulled-out. The materiais properties are listed in Table I.

Tabla I Propiedades de los materiales empleados / Table I Properties of materials

\begin{tabular}{|c|c|c|c|}
\hline \multicolumn{4}{|c|}{ PROPIEDADES DE LA MATRIZ CONVENCIONAL M1 (PROPERTIES OF CONVENTIONAL MATRIX M1) } \\
\hline $\begin{array}{l}\text { DOSIFICACIÓN } \\
\text { (MIX DESIGN) } \\
\text { C/Ar/A/MS }\end{array}$ & $\begin{array}{l}\text { RESISTENCIA A } \\
\text { COMPRESIÓN } \\
\text { (COMPRESSIVE } \\
\text { STRENGHT) } \\
\text { (MPa) }\end{array}$ & $\begin{array}{c}\text { MÓDULO DE ELASTICIDAD } \\
\text { (MODULUS OF ELASTICITY) } \\
\text { (GPa) }\end{array}$ & $\begin{array}{l}\text { RESISTENCIA A TRACCIÓN } \\
\text { (TENSILE STRENGHT) } \\
\text { (MPa) }\end{array}$ \\
\hline $1 / 3 / 0,5 /-$ & 57,78 & 21,5 & 10,2 \\
\hline \multicolumn{4}{|c|}{ PROPIEDADES DE LA MATRIZ DE ALTA RESISTENCIA M2 (PROPERTIES OF HIGH STRENGHTMATRIX M2) } \\
\hline $\begin{array}{l}\text { DOSIFICACIÓN } \\
\text { (MIX DESIGN) } \\
\text { C/Ar/A/MS }\end{array}$ & $\begin{array}{l}\text { RESISTENCIA A } \\
\text { COMPRESIÓN } \\
\text { (COMPRESSIVE } \\
\text { STRENGHT) } \\
\text { (MPa) } \\
\end{array}$ & $\begin{array}{l}\text { MÓDULO DE ELASTICIDAD } \\
\text { (MODULUS OF ELASTICITY) } \\
\text { (GPa) }\end{array}$ & $\begin{array}{c}\text { RESISTENCIA A TRACCIÓN } \\
\text { (TENSILE STRENGHT) } \\
\text { (MPa) }\end{array}$ \\
\hline $1 / 3 / 0,5 / 0,2$ & 76,51 & 25,3 & ...-- \\
\hline \multicolumn{4}{|c|}{ PROPIEDADES DE LA FIBRA DE ACERO (PROPERTIES OF STEEL FIBER) } \\
\hline $\begin{array}{l}\text { FIBRA } \\
\text { (F/BER) }\end{array}$ & $\begin{array}{l}\text { DIÁMETRO } \\
\text { (DIAMETER) } \\
(\mathrm{mm})\end{array}$ & $\begin{array}{c}\text { RESISTENCIA A TRACCIÓN } \\
\text { (TENSILE STRENGHT) } \\
\text { (GPa) }\end{array}$ & $\begin{array}{l}\text { LONGITUD EMBEBIDA } \\
\text { (EMBEDDED LENGHT) } \\
(\mathrm{mm})\end{array}$ \\
\hline$A C$ & 0,6 & 1,8 & 30 \\
\hline AO & 0,6 & 1,8 & 26,5 \\
\hline AR & 0,4 & 1,8 & 12,7 \\
\hline \multicolumn{4}{|c|}{ PROPIEDADES DE LA FIBRA DE NYLON (PROPERTIES OF NYLON FIBER) } \\
\hline \multicolumn{2}{|c|}{$\begin{array}{l}\text { DIÁMETRO } \\
\text { (DIAMETER) } \\
(\mathrm{mm})\end{array}$} & $\begin{array}{l}\text { RESISTENCIA A TRACCIÓN } \\
\text { (TENSILE STRENGHT) } \\
\text { (MPa) }\end{array}$ & $\begin{array}{l}\text { LONGITUD EMBEBIDA } \\
\text { (EMBEDDED LENGHT) } \\
(\mathrm{mm})\end{array}$ \\
\hline \multicolumn{2}{|c|}{0,4} & 85 & 12,7 \\
\hline
\end{tabular}

${ }^{*} \mathrm{C}=$ Cemento/Cement; $\mathrm{Ar}=$ Arena/Sand; $\mathrm{A}=$ Agua/Water; $\mathrm{MS}=$ Microsílice/Silica fume 
A continuación (ver Tabla II) se presentan algunos resultados de los obtenidos dentro de un programa desarrollado para estudiar el efecto de dos fibras de naturaleza distinta (acero y nylon) contrastadas con distinta geometría, tipos de matriz (con y sin humo de
Next (see Table II) some results are presented from the program developed to study the effect of two types of fibers (steel and nylon) with different geometry, types of matrix (with and without silica fume), fiber

Tabla II Programa experimental de los ensayos presentados / Table II Experimental program

\begin{tabular}{|c|c|c|c|c|c|c|c|c|c|}
\hline \multirow{2}{*}{ 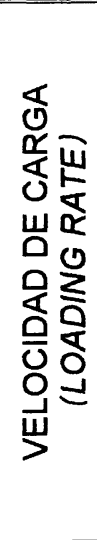 } & \multirow[b]{2}{*}{ 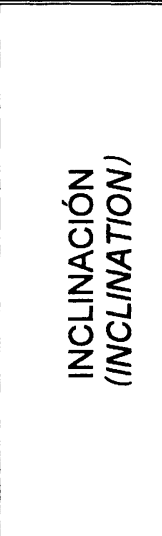 } & \multicolumn{4}{|c|}{$\begin{array}{c}\text { MATRIZ SIN MICROSILICE } \\
\text { (MATRIX WITHOUT SILICA FUME) } \\
\text { M1 } \\
\text { TIPO DE FIBRA } \\
\text { (FIBER TYPE) } \\
\end{array}$} & \multicolumn{4}{|c|}{$\begin{array}{c}\text { MATRIZ CON MICROSILICE } \\
\text { (MATRIX WITH SILICA FUME) } \\
\text { M2 } \\
\text { TIPO DE FIBRA } \\
\text { (FIBER TYPE) } \\
\end{array}$} \\
\hline & & 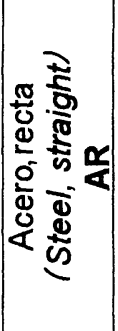 & 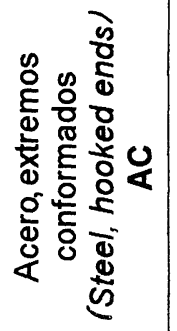 & 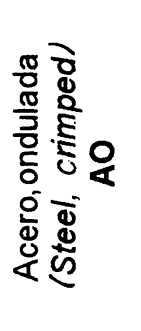 & 을 & 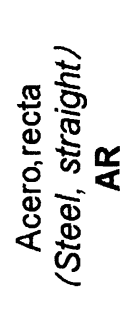 & 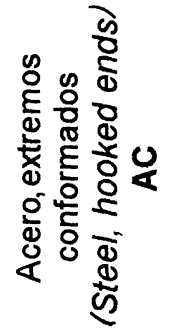 & 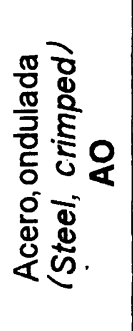 & 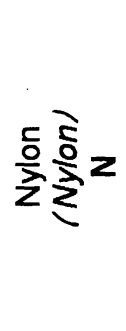 \\
\hline \multirow{2}{*}{ V1 } & \begin{tabular}{|c|}
0 \\
grados \\
(degrees) \\
AO \\
\end{tabular} & & & & & & & & \\
\hline & \begin{tabular}{|c|}
27 \\
grados \\
(degrees) \\
A2
\end{tabular} & & & & & & & & \\
\hline \multirow{2}{*}{ V2 } & \begin{tabular}{|c|}
0 \\
grados \\
(degrees) \\
A0 \\
\end{tabular} & & & & & & & & \\
\hline & \begin{tabular}{|c|}
27 \\
grados \\
(degrees) \\
A2
\end{tabular} & & & & & & & & \\
\hline \multirow{2}{*}{ V3 } & \begin{tabular}{|c|}
0 \\
grados \\
(degrees) \\
$\mathrm{AO}$ \\
\end{tabular} & 1 & & & & & & & \\
\hline & \begin{tabular}{|c|}
27 \\
grados \\
(degrees) \\
A2
\end{tabular} & & & & & & & & \\
\hline \multirow{2}{*}{ V4 } & $\begin{array}{c}0 \\
\text { grados } \\
\text { (degrees) } \\
\mathrm{AO} \\
\end{array}$ & & & & & & & & \\
\hline & \begin{tabular}{|c|}
27 \\
grados \\
(degrees) \\
A2 \\
\end{tabular} & & & & & & & & \\
\hline \multicolumn{10}{|c|}{$\mathrm{V} 1=0.1 \mu \mathrm{m} / \mathrm{s}(\approx 0.000005 \mathrm{in} / \mathrm{s})$} \\
\hline \multicolumn{10}{|c|}{$\mathrm{V} 2=5.6 \mu \mathrm{m} / \mathrm{s}(\approx 0.00025 \mathrm{in} / \mathrm{s})$} \\
\hline \multicolumn{10}{|c|}{$\mathrm{V} 3=38-94 \mathrm{~mm} / \mathrm{s}(\approx 1.96-4.18 \mathrm{in} / \mathrm{s})$} \\
\hline
\end{tabular}


sílice), distinta inclinación de las fibras y distintas velocidades de carga. Como puede observarse en dicha Tabla II , la distinta geometría de las fibras de acero se estudiaron siempre a la misma velocidad de carga V2. La fibra de nylon no pudo ensayarse con la matriz M1. En la bibliografía adjunta se pueden encontrar resultados adicionales $(6,8,11,12)$.

\section{DISCUSIÓN DE LOS RESULTADOS EXPERIMENTALES}

Un resumen de los resultados experimentales, obtenidos en los ensayos estáticos de extracción de fibras de nylon de una matriz de mortero, los podemos encontrar en la Tabla III. En ella aparece el valor de las fuerzas de adherencia máximas $\left(\mathrm{F}_{\mathrm{m}}\right)$, obtenidas para una serie de 16 fibras, el valor de la fuerza en el momento en que la fibra está totalmente separada de la matriz $\left(F_{a}\right)$ y el valor de las fuerzas de rozamiento últimas antes de convertirse en $0\left(F_{b}\right)$. Estos puntos se pueden observar en la Fig. 3 . inclination and loading rates. It can be seen in Table II that steel fibers with different geometry were all tested at the V2 rate of loading. Nylon fiber was not tested with matrix M1. Additional results of this program can be found in the references attaches $(6,8,11,12)$

\section{DISCUSSION OF EXPERIMENTAL RESULTS}

Table III shows a selection of experimental results for static pull-out nylon fibers test. $F_{m}$ represents the maximum bonding forces obtained for a number of 16 fibers being pulled out, $F_{a}$ is the load value when the fiber is totally separated from the matrix and $F_{b}$ is the ultimate frictional force before dropping to 0 . These points can be seen in Fig. 3.

Tabla III Resultados experimentales de los ensayos estáticos de pull-out de fibras de nylon

Table III Experimental results of quasi-static pull-out test for nylon fibers

\begin{tabular}{|c|c|c|c|c|c|c||}
\hline $\begin{array}{c}\text { PROBETA } \\
\text { (SPECIMEN) }\end{array}$ & $\mathrm{F}_{\mathrm{m}}(\mathrm{N})$ & $\mathrm{F}_{\mathrm{A}}(\mathrm{N})$ & $\mathrm{F}_{\mathrm{B}}(\mathrm{N})$ & $\begin{array}{c}\text { PENDIENTE ab } \\
\text { (SLOPE ab) }\end{array}$ & $\mathrm{d}_{\mathrm{cr}}(\mathrm{mm})$ & $\mathrm{d}_{\mathrm{B}}(\mathrm{mm})$ \\
\hline M2NV2A01 & 47,6 & 29,0 & 4,5 & $-0,8$ & 0,69 & 10,6 \\
\hline M2NV2A02 & 46,7 & 28,4 & 5,8 & $-0,8$ & 0,64 & 9,8 \\
\hline M2NV2A21 & 65,1 & 31,1 & 9,0 & $-0,5$ & 0,66 & $>12,7$ \\
\hline M2NV2A22 & 53,0 & 31,1 & 20,0 & $-0,7$ & 1,02 & $>12,7$ \\
\hline M2NV2A23 & 77,4 & 35,6 & 20,0 & $-0,7$ & 0,91 & $>12,7$ \\
\hline
\end{tabular}

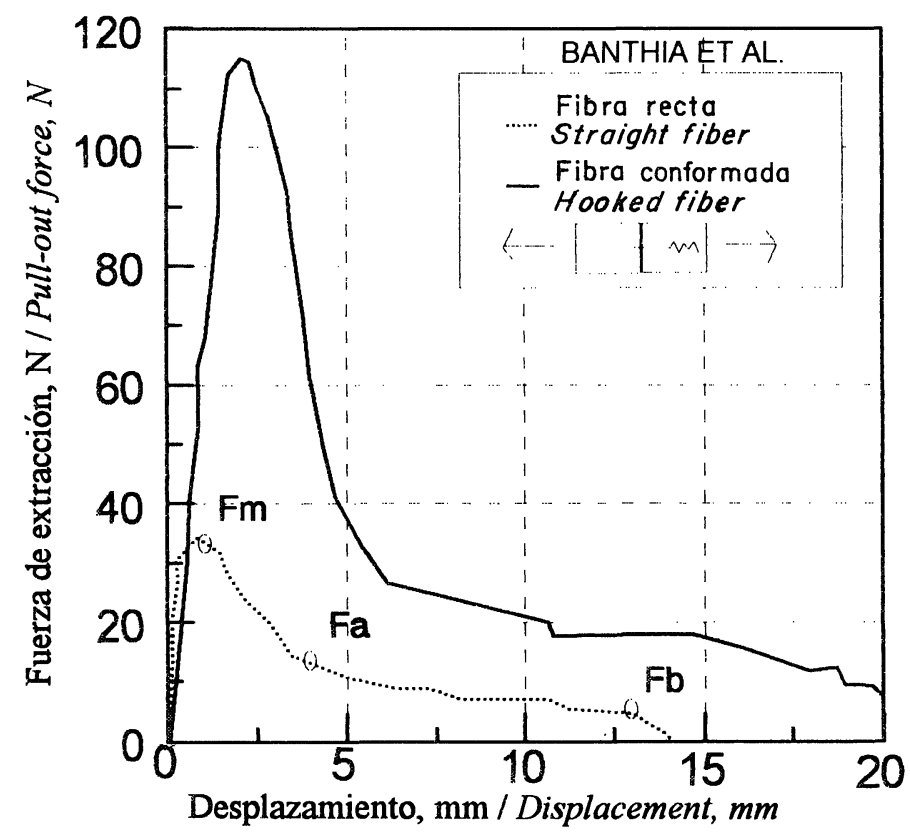

Fig. 3.-Efecto de la geometría de la fibra en el ensayo de pull-out. Fig. 3.- Effect of fiber geometry on the pull-out of aligned fibers. 
Los ensayos dinámicos de extracción de fibras de nylon se representan en la Tabla IV. En ella, $F_{A}+F_{B}$ representan las fuerzas de adherencia, medidas mediante las células de carga de tipo anillo y $\mathrm{F}_{\mathrm{C}}-\mathrm{F}_{\mathrm{I}}$ representan la misma medida, obtenida restando las fuerzas de inercia a las fuerzas del impacto.
Dynamic nylon pull-out test results are shown in Table IV. $F_{A}+F_{B}$ represent the bonding force measured by the ring load cells and $F_{C}-F_{I}$ represents the same force measured subtracting inertial force from the one measured with the impact load cell.

Tabla IV Resultados experimentales de los ensayos dinámicos de pull-out de fibras de nylon

Table IV Experimental results of dynamic pull-out test for nylon fibers

\begin{tabular}{|c|c|c|c|c|c|c|}
\hline \multirow{2}{*}{$\begin{array}{c}\text { Ensayo } \\
\text { (Test) }\end{array}$} & \multicolumn{2}{|c|}{$\mathrm{AO}$} & \multicolumn{2}{|c|}{$\mathrm{A} 2$} & \multirow{2}{*}{$\frac{\mathrm{AO}}{\mathrm{d}_{\max }}$} & \multirow{2}{*}{$\begin{array}{l}\mathrm{A} 2 \\
\mathrm{~d}_{\max }\end{array}$} \\
\hline & $F_{A}+F_{B}$ & $F_{c}-F_{i}$ & $\mathrm{~F}_{\mathrm{A}}+\mathrm{F}_{\mathrm{B}}$ & $F_{c}-F_{i}$ & & \\
\hline V3 & 89,0 & 120,2 & 122,4 & 99,7 & ---- & 1,6 \\
\hline v3 & 86,3 & 90,3 & 126,4 & 109,0 & 1,0 & 1,9 \\
\hline V3 & 116,1 & 109,9 & 118,4 & 98,3 & 1,3 & 2,0 \\
\hline V4 & ---- & $\cdots$ & 126,8 & 109,0 & ---- & 2,0 \\
\hline V4 & ---- & --- & 131,3 & --.. & ---- & 2,1 \\
\hline V4 & --.- & ---- & 115,7 & --.- & ---- & 1,8 \\
\hline
\end{tabular}

Los resultados obtenidos en el ensayo de pull-out de fibras de acero aparecen en la Tabla V. En este caso, los valores son los correspondientes para la extracción de una sola fibra.

\subsection{Efecto del tipo de fibra}

La influencia de la geometría de la fibra se pone de manifiesto en la Fig. 3. Una fibra recta ofrece una menor resistencia a la extracción que cuando ésta tiene los extremos conformados, pues se realiza un anclaje mecánico en las terminaciones, además de la adherencia superficial. Una vez superada la carga máxima el comportamiento es similar puesto que la adherencia se debe, exclusivamente, a las fuerzas de rozamiento. La tenacidad aumenta considerablemente empleando fibras onduladas o de extremos conformados en lugar de fibras rectas. La diferencia entre una fibra de acero y otra de nylon se pone de manifiesto por la menor adherencia superficial de la fibra de nylon y la alta deformabilidad de la misma, lo que provoca que la separación de las fibras se producta inmediatamente. La Fig. 4 compara los resultados obtenidos con fibra de acero y fibra de nylon; mientras que la carga máxima es menor para las fibras de nylon, la deformación correspondiente a ese punto es mayor. Dada la alta deformabilidad de la fibra, el período lineal de la curva fuerza de extracción-desplazamiento es muy breve, alcanzando aproximadamente el $10 \%$ de la carga máxima, frente a un $40 \%$ para las fibras metálicas.
Results from steel fibers pull-out are shown in Table $V$. The values correspond to the extraction of a single fiber.

\subsection{Effect of the type of fiber}

The geometry of the fiber effect manifests in Fig. 3. An aligned fiber offers a smaller resistance to the extraction than the fiber having bended ends, since a mechanical anchorage is acting in addition to the superficial adherence. Once the maximum load is reached the behavior is similar since the adherence is due exclusively to the frictional forces. Toughness increases considerably by using crimped or hooked fibers instead of straight ones. The difference between a steel and nylon fiber evidences itself by the smaller superficial bond of the nylon fiber and the high strain of the same, resulting in an early separation of the fiber from the matrix. Fig. 4 compares results from both types of fibers, nylon and steel. While maximum bonding load is lower for nylon fibers, strain at the maximum load is higher. Due to the high fiber ductility the lineal period in the plot bonding forces/slip is very small, corresponding to $10 \%$ of maximum load approx. while for steel fiber is about $40 \%$ 
Tabla V Resultados experimentales del pull-out de fibras de acero

Table $V$ Experimental results for steel fiber pull-out test

\begin{tabular}{|c|c|c|c|c|c|c|}
\hline $\begin{array}{l}\text { PROBETA } \\
\text { (SPECIMEN) }\end{array}$ & $\begin{array}{l}\text { TIPO DE FIBRA } \\
\text { (FIBER TYPE) }\end{array}$ & $\begin{array}{c}\text { TIPO DE } \\
\text { MATRIZ } \\
\text { (MATRIX TIPE) }\end{array}$ & $\begin{array}{l}\text { ENSAYO } \\
\text { (TEST) }\end{array}$ & $\begin{array}{c}\text { ORIENTACIÓN } \\
\text { (INCLINATION) } \\
\text { (grados) } \\
\text { (degrees) }\end{array}$ & $\begin{array}{l}\text { CARGA } \\
\text { MÁXIMA } \\
\text { (MAXIMUM } \\
\text { LOAD) } \\
\text { (N) }\end{array}$ & $\begin{array}{l}\text { DESPLAZAM. } \\
\text { (DISPLACEM.) } \\
(\mathrm{mm})\end{array}$ \\
\hline $\begin{array}{l}\text { ACM } 1 \text { V } 2 A O \\
\text { AOM } 1 \mathrm{~V} 2 \mathrm{AO}\end{array}$ & $\begin{array}{c}\text { Acero, } \\
\text { Extremos } \\
\text { Conformados } \\
\text { ((Stell, Hooked } \\
\text { Ends) } \\
\text { Acero, } \\
\text { Ondulada } \\
\text { (Steel, } \\
\text { Crimped) }\end{array}$ & $\begin{array}{c}\text { Sin } \\
\text { microsilice } \\
\text { (Without } \\
\text { silica } \\
\text { fume) } \\
\text { Sin } \\
\text { microsilice } \\
\text { Without } \\
\text { silica } \\
\text { fume) }\end{array}$ & $\begin{array}{l}\text { Estático } \\
\text { (Static) } \\
\text { Estático } \\
\text { (Static) }\end{array}$ & 0 & $140^{* *}$ & * \\
\hline $\begin{array}{l}\mathrm{ACM} 2 \mathrm{~V} 2 \mathrm{AO} \\
\text { AOM } 2 \mathrm{~V} 2 \mathrm{AO}\end{array}$ & $\begin{array}{c}\text { Acero, } \\
\text { Extremos } \\
\text { Conformados } \\
\text { (Steel, Hooked } \\
\text { Ends) } \\
\text { Acero, } \\
\text { Ondulada } \\
\text { (Steel, } \\
\text { Crimped) }\end{array}$ & $\begin{array}{l}\quad \text { Con } \\
\text { microsilice } \\
\text { (With silica } \\
\quad \text { fume) } \\
\quad \text { Con } \\
\text { microsilice } \\
\text { (With silica } \\
\quad \text { fume) }\end{array}$ & $\begin{array}{l}\text { Estático } \\
\text { (Static) } \\
\text { Estático } \\
\text { (Static) }\end{array}$ & 0 & $\begin{array}{l}319 * * \\
659 * *\end{array}$ & * \\
\hline $\begin{array}{l}\text { ARM } 1 \text { V } 2 A O \\
\text { ARM } 1 \mathrm{~V} 2 A 2\end{array}$ & $\begin{array}{c}\text { Acero, Recta } \\
\text { (Steel Straight) } \\
\text { Acero, Recta } \\
\text { (Stell Straight) }\end{array}$ & $\begin{array}{c}\text { Sin } \\
\text { microsilice } \\
\text { (Without } \\
\text { silica } \\
\text { fume) } \\
\text { Sin } \\
\text { microsilice } \\
\text { (Without } \\
\text { silica } \\
\text { fume) }\end{array}$ & $\begin{array}{l}\text { Estático } \\
\text { (Static) } \\
\\
\text { Estático } \\
\text { (Static) }\end{array}$ & 27 & 81,53 & 0,193 \\
\hline ARM 1 V $3 A O$ & $\begin{array}{c}\text { Acero, Recta } \\
\text { (Steel, } \\
\text { Straight) } \\
\\
\text { Acero, Recta } \\
\text { (Steel, } \\
\text { Straight) }\end{array}$ & $\begin{array}{c}\text { Sin } \\
\text { microsilice } \\
\text { (Without } \\
\text { silica } \\
\text { fume) } \\
\text { Sin } \\
\text { microsilice } \\
\text { (Without } \\
\text { silica } \\
\text { fume) }\end{array}$ & $\begin{array}{c}\text { Dinámico } \\
\text { (Dynamic) } \\
\text { Dinámico } \\
\text { (Dynamic) }\end{array}$ & 27 & 204,83 & 1,031 \\
\hline
\end{tabular}

* No se consideran estos valores, pues la medida registrada no corresponde al deslizamiento relativo entre la fibra y la matriz exclusivamente.

Those values are not considered, values registered correspond to relative slip between matrix and fiber and others.

** Valores obtenidos para longitudes embebidas de 27 y $30 \mathrm{~mm}$

Results for embedded lengths of 27 and $30 \mathrm{~mm}$.

NOTA: Las fibras con extremos conformados y las fibras plegadas no son fibras comerciales; se han elaborado a partir de una fibra recta /Crimped fibers and hooked end fibers are not commercially available. 


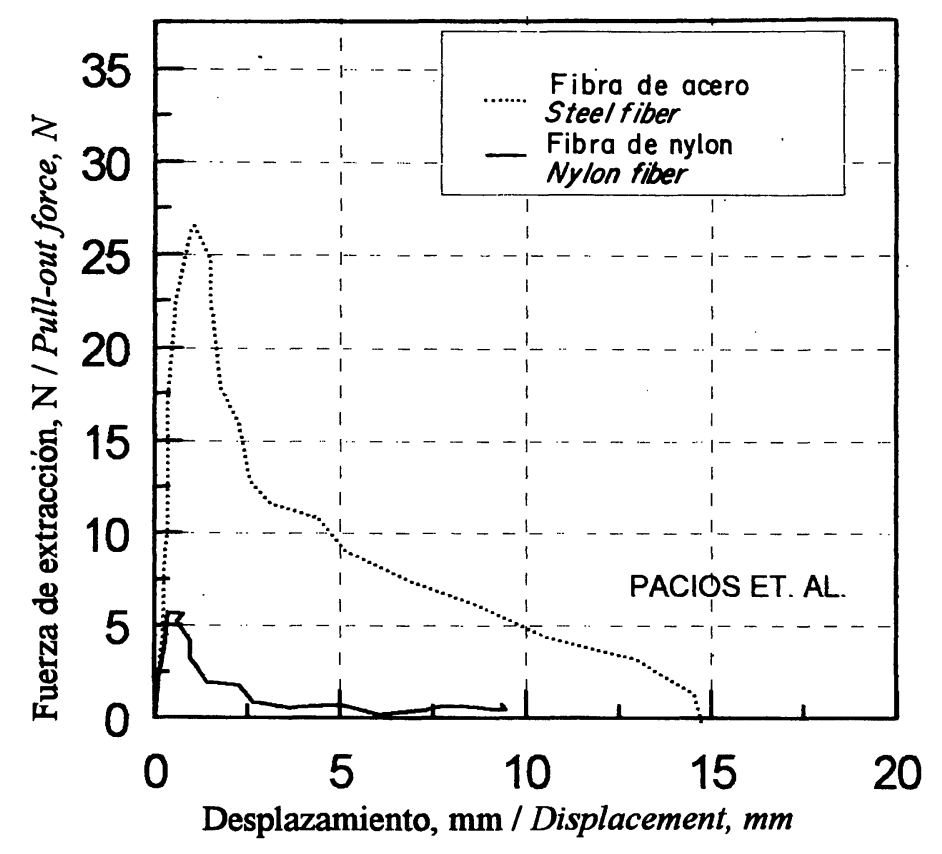

Fig. 4.- Efecto de la naturaleza de la fibra en el ensayo de pull-out.

Fig. 4.- Effect of the type of fiber on the pull-out test.

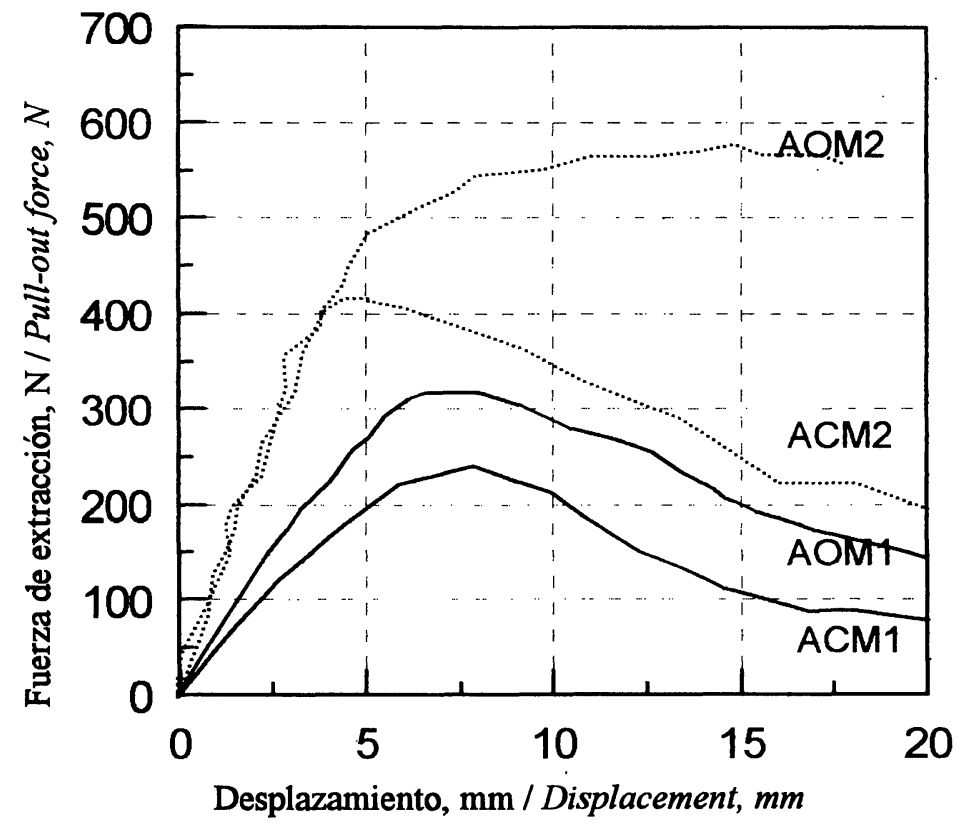

Fig. 5.- Efecto de la matriz en el ensayo de pull-out.

Fig. 5.- Effect of the matrix on the pull-out test.

\subsection{Efecto del tipo de matriz}

Dada la necesidad de garantizar una mejor adherencia entre una parte de la matriz y la fibra con respecto a la otra mitad de la matriz, ésta se mejoró con un $20 \%$ de humo de sílice. Los resultados preliminares realizados son los que se muestran a continuación. En la Fig. 5 se representa la extracción de dos fibras, una fibra con los extremos conformados (AC) y una fibra ondulada (AO), a lo largo de toda su longitud.

\subsection{Effect of type of matrix}

Given the need of guaranteeing a better adherence between a part of the matrix and the fiber with respect to other half of the matrix, the later was improved with a $20 \%$ of silica fume. Next the preliminary results are shown. Fig. 5 represents the pull-out of two fibers, $a$ fiber with hooked ends $(A C)$ and a crimped fiber $(A O)$. 
Mientras que para la primera fibra se produjo siempre la extracción de ésta, en el caso de la fibra ondulada y la matriz de mayor resistencia, el modo de fallo se produjo por rotura de la fibra. Estos resultados se ven confirmados por los obtenidos por otros investigadores (5).

\subsection{Efecto de la inclinación de la fibra}

El comportamiento es similar para las fibras de nylon y las de acero. La Fig. 6a compara el efecto adicional, tanto en tenacidad como en carga máxima de extracción para las fibras de nylon, al estar inclinadas con la dirección del esfuerzo. En la Fig. $6 \mathrm{~b}$ se puede ver que aumentando la inclinación de la fibra, la fuerza máxima de adherencia aumenta. Este incremento es distinto para las distintas velocidades de carga, observándose un incremento pequeño, del orden del $3 \%$ para los ensayos estáticos y un incremento que varía entre un $35-100 \%$ para los ensayos dinámicos. Se aprecia que para los ensayos dinámicos e inclinaciones superiores a los $27^{\circ}$, la dispersión de los resultados experimentales aumenta. Los desplazamientos obtenidos en los puntos de carga máxima no varían a la misma proporción que las fuerzas de adherencia, consiguiéndose unos incrementos menores (11).

Las fibras de nylon reproducen un comportamiento similar al de las fibras de acero para los ensayos estáticos. Sin embargo, al extraer fibras inclinadas a altas velocidades de carga ésta no aumenta siguiendo la razón esperada, obteniéndose valores similares, aunque la velocidad de carga sea mayor.

\subsection{Efecto de la velocidad de carga}

La Fig. 7a muestra los valores obtenidos para la extracción de una fibra recta de acero en relación con la velocidad de deformación. Para todas las inclinaciones de fibras se experimenta un aumento para $p_{\max }$ al aumentar la velocidad de deformación. La contribución del doblado de la fibra cobra un significado importante, que ha servido de base en trabajos de investigación (6).

Las fibras de nylon embebidas en una matriz tienen un comportamiento similar ante el efecto de la matriz con microsílice e inclinación de la fibra, pero no siguen el mismo comportamiento al aumentar la velocidad de carga.(Ver Fig. 7b). Esto puede ser debido a que las fibras de nylon se separan en los primeros estadios de carga de la matriz y es, a partir de entonces, cuando los esfuerzos de rozamiento se encargan de la transferencia de esfuerzos. Las fuerzas de rozamiento no parecen ser tan sensibles a la velocidad de carga como las de adherencia.
While first fiber was always pulled out, the crimped fiber and the matrix with higher strength broke while it was being pulled, thus changing the type of failure. These results are confirmed by the obtained for other researchers. (5)

\subsection{Effect of the fiber inclination}

Behavior is similar for steel and nylon fibers. Fig. $6 a$ compares the additional effect for nylon inclined fibers, as for maximum load and toughness. Fig. $6 b$ shows that the higher the fiber inclination is, the higher the maximum adherence loads are. This increment is different for the different loading rates, being observed an increase of a $3 \%$ for the static test and an increase that varies between a $35-100 \%$ for the dynamic tests. It is detected that for dynamic tests and inclinations bigger than $27^{\circ}$ the dispersion of experimental results increases. The displacement obtained at the maximum load points does not vary to the same rate as the adherence forces and smaller increments are reached (11).

Nylon fibers present a similar behavior as steel fibers in static test. However, pulling inclined fibers at high loading rates does not reach expected maximum forces.

\subsection{Effect of the loading rate}

Fig. 7a shows the results for the pull-out of a straight steel fiber for different rates of loading. For all fiber inclinations an increment for $p_{\max }$ is experienced upon increasing the loading rate. The contribution of the bending of the fiber gets an important meaning that is modeled in research projects (6).

Nylon fibers embedded in a matrix have a similar behavior for the fiber inclination effect but do not follow the same behavior when loading rate is incremented. (See Fig. 7b). This may be related to the nylon fiber debonding from the matrix at very low levels. At this point frictional forces are responsible for transfer load. Friction forces are not so sensitive to loading rate as bonding forces. 


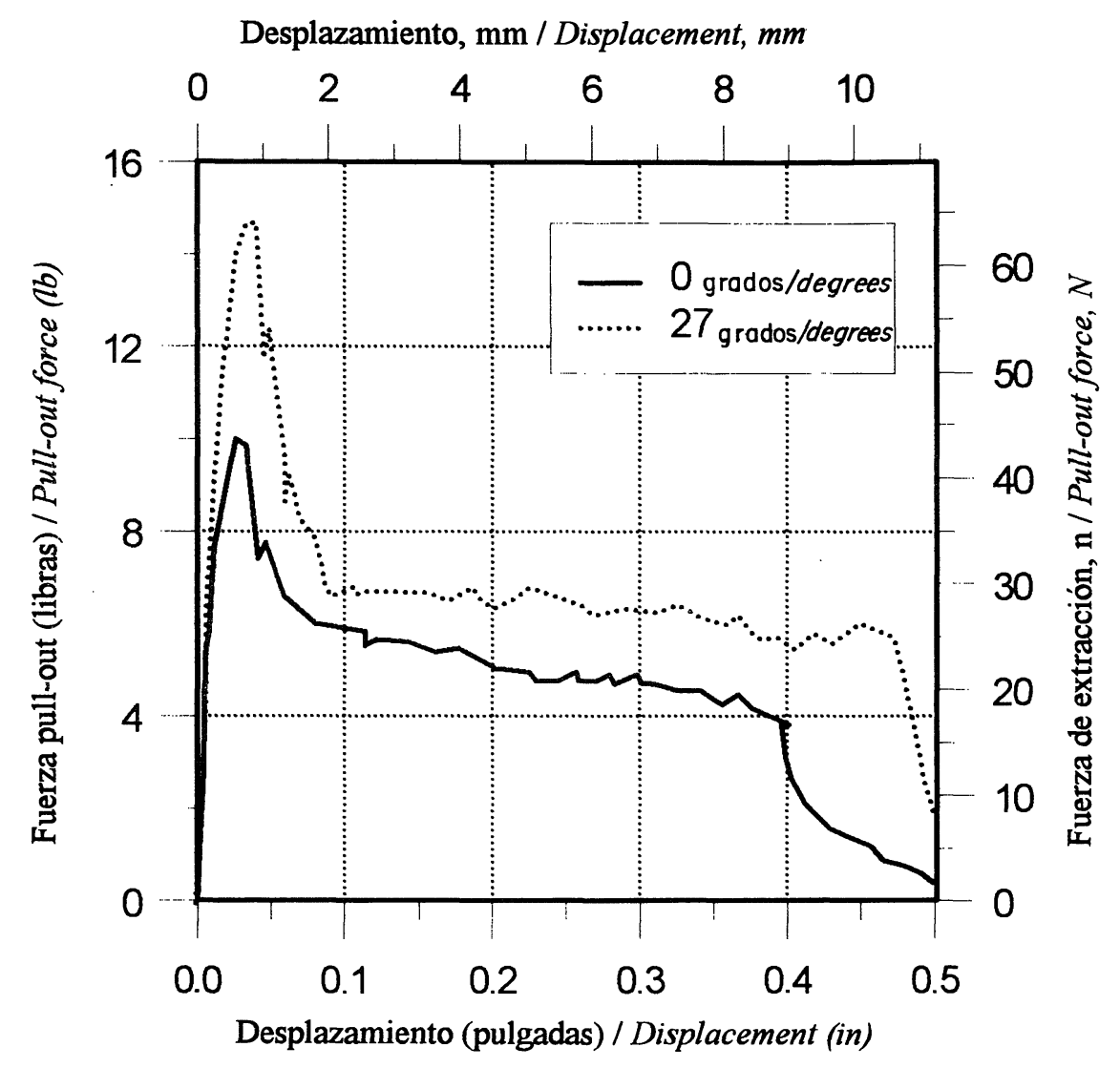

a)

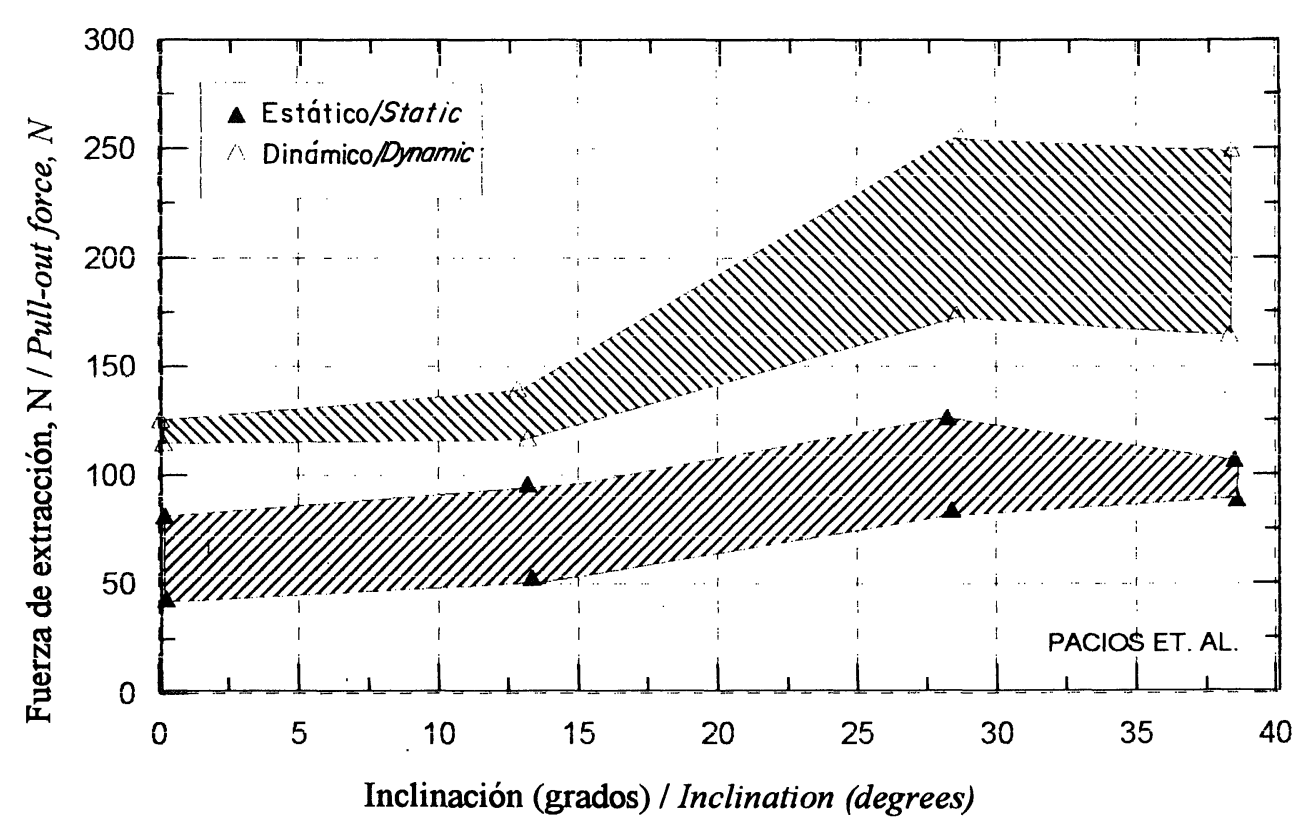

b)

Fig. 6.- a) Influencia de la inclinación de las fibras sobre la tenacidad y fuerza de arrancamiento de fibras de nylon; b) Influencia de la inclinación de las fibras sobre la fuerza de arrancamiento de las fibras de acero.

Fig. 6.- a) Effect of fiber inclination on toughness and debonding forces for nylon fibers pull-out test; b) Effect of fiber inclination on toughness and debonding forces for steel fibers pull-out test. 


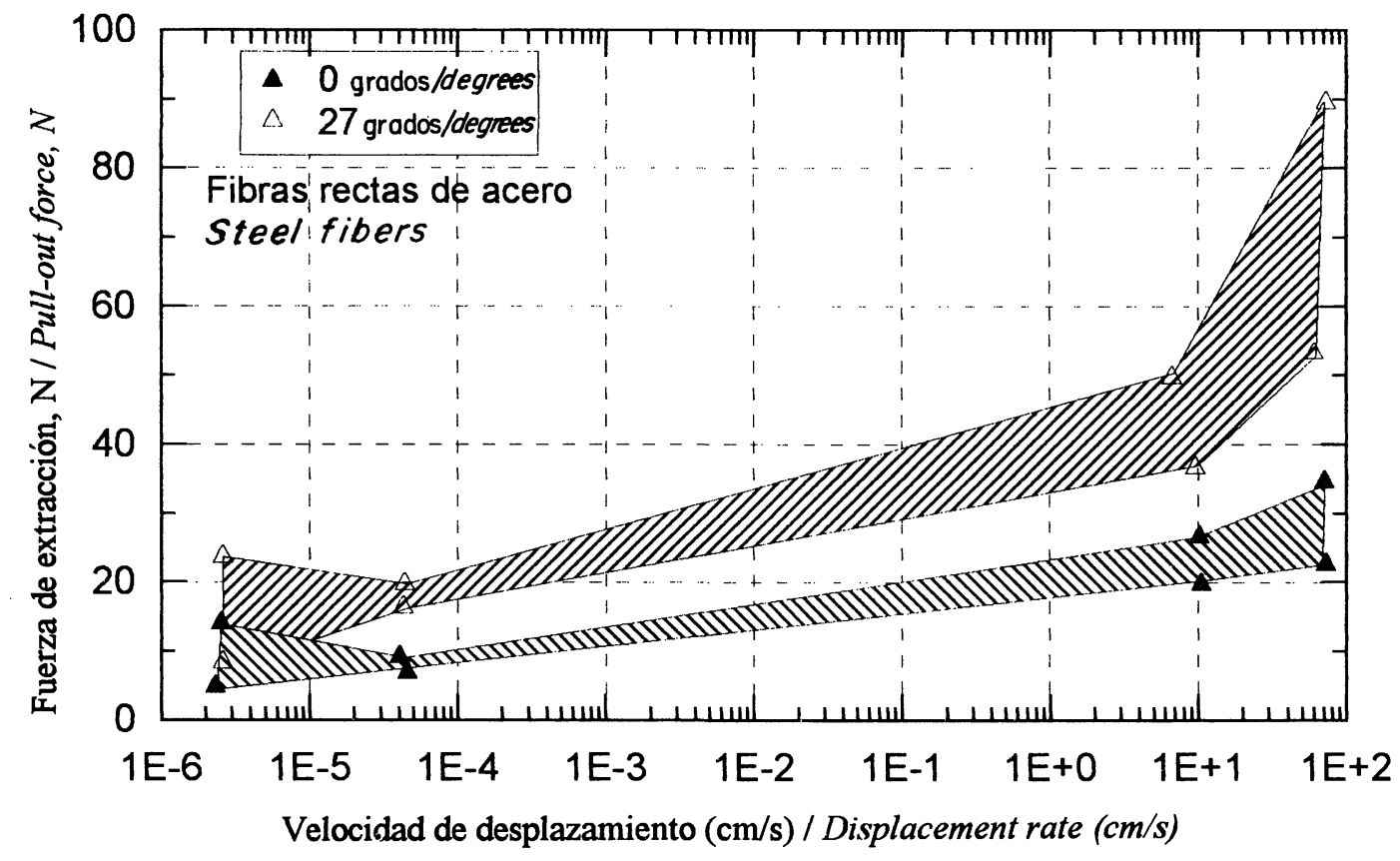

a)

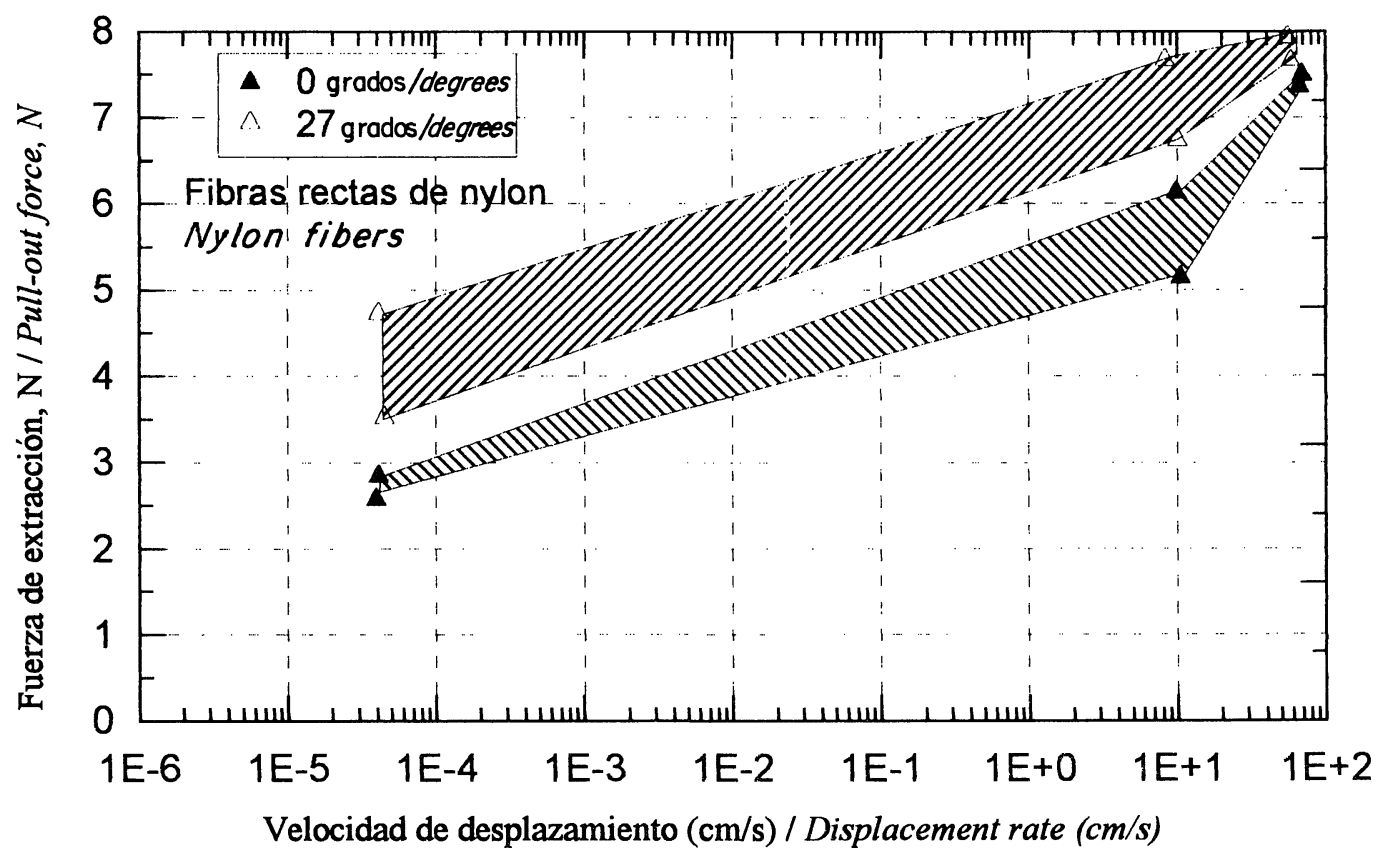

b)

Fig. 7.- Efecto de la velocidad de carga en el ensayo de pull-out (a: fibras de acero; b: fibras de nylon)

Fig. 7.- Effect of loading rate on the pull-out test (a: steel fibers; $b$ : nylon fibers). 


\section{CONCLUSIONES}

La caracterización de la interfase debe ser conocida para evaluar el comportamiento mecánico de los hormigones reforzados con fibras. Estudiadas experimentalmente distintas variables que pueden intervenir en los mecanismos de adherencia, se pone de manifiesto que todas ellas modifican el comportamiento mecánico de la interfase.

La técnica experimental descrita se ha utilizado en probetas con fibras metálicas y probetas con fibras de nylon, observándose buenos resultados en ambos casos. Se ha de señalar que, dada la menor adherencia que las fibras sintéticas tienen con matrices de cemento, se recomienda aumentar la rigidez de la probeta, mejorando la naturaleza de la matriz o utilizando siempre grupos de fibras.

Se puede mejorar la adherencia actuando sobre la composición de la propia matriz o actuando sobre el elemento de refuerzo. Si mejoramos la matriz con la incorporación de una adición mineral que da lugar a en una matriz más densa y, por consiguiente, con una mejor adherencia, se consiguen aumentar las resistencias hasta en un $100 \%$. Al mismo tiempo se observa que, combinando las dos acciones, una matriz con humo de sílice y una fibra de acero ondulada, a lo largo de la generatriz, se puede modificar el tipo de fallo, produciéndose la rotura de la fibra. Al aumentar la inclinación de la fibra y la velocidad de carga, también se modifican las fuerzas de adherencia.

Las fibras de nylon embebidas en una matriz tienen un comportamiento similar ante el efecto de la matriz con microsílice e inclinación de la fibra, pero no siguen el mismo comportamiento al aumentar la velocidad de carga. Esto puede ser debido a que las fibras de nylon se separan en los primeros estadíos de carga de la matriz y es a partir de entonces cuando los esfuerzos de rozamiento se encargan de la transferencia de esfuerzos. Las fuerzas de rozamiento no parecen ser tan sensibles a la velocidad de carga como las de adherencia.

\section{AGRADECIMIENTOS}

La realización de este trabajo experimental ha sido posible gracias a la ayuda prestada por el NSF Center for Advanced Cement Based Materials y por el Ministerio de Educación y Cultura en el programa de "Formación de personal investigador y docente".

\section{CONCLUSIONS}

The characterization of the interface must be known in order to evaluate the mechanical behavior of the composite. Different variables have been experimentally studied that may collaborate in the adherence mechanisms. This study shows that all of them modify the mechanical behavior of the interface.

The experimental technique described has been proved with steel and nylon fibers, with good results in both cases. Due to the lower adherence that synthetic fibers have with cementitious matrixes it is recommended to enlarge the specimen stiffness by improving the matrix or testing a group of fibers instead a single one.

Adherence can be improved by acting on the composition of the matrix or the reinforcement element. Improving the matrix with the incorporation of a mineral admixture results in a denser matrix and consequently better adherence bonding strength can improve in a 100\% At the same time, is observed that combining the two actions, crimped fiber and the matrix with higher strength, the type of failure is modified to a broken fiber. Increasing the inclination of the fiber and the loading rate adherence forces are also increased.

Nylon fibers embedded in a matrix have a similar behavior for the fiber inclination effect but do not follow the same behavior when loading rate is increased. This may be related to the nylon fiber debonding from the matrix at very low levels. At this point frictional forces are responsible for transfer load. Friction forces are not so sensitive to loading rate as bonding forces.

\section{ACKNOWLEDGEMENTS}

Support of National Science Foundation Center for Science and Technology of Advanced Cement-based Materials is gratefully appreciated. Thanks are extended to the Ministry of Culture and Education with the Program "Research and Educational Training" 


\section{BIBLIOGRAFÍA}

(1) R.J. GRAY: Journal of Materials Science, 1984, 19, (3), 861-870.

(2) S.P. SHAH, S.E. SWARTZ y C. OUYANG: en "Fracture Mechanics of Concrete", 1995, John Wiley \& Sons, Inc., New York, 484-493.

(3) P. BARTOS: International Journal of Cement Composites and Lightweight Concrete, 1981, 3, 159-177.

(4) A. PACIOS y M. FERNÁNDEZ CÁNOVAS, en "I Rencontre Transfronralière sur la Mécanique et la Phisique dels Matériaux Biphasiques", (ed A. Mateo et al), 1996, Barcelona, 201-206.

(5) N. BANTHIA y J.F. TROTTIER: Cement and Concrete Research, 1991, 21,

(6) C. OUYANG, A. PACIOS y S.P. SHAH: Materials and Structures, 1995, 28, 83-91.

(7) A. PACIOS ALVAREZ, M. FERNÁNDEZ CÁNOVAS y L. VILLANUEVA DOMÍNGUEZ: en "Aplicaciones arquitectónicas de los materiales compuestos y aditivados", 1993, ETSAM, Madrid, 241-254.

(8) K. VITTUARI: in "Essais d'arrachement de fibres synthétiques ancrées dans une matrice de mortier", 1993, Proyecto fin de carrera, LCPC, París, 58 pp.

(9) V. LI, Y. WANG y S. BACKER: Composites, 1990, 21, (2), 132-140.

(10) A. PACIOS: en "Medida de la resistencia a impacto de la interfase fibra-matriz en hormigones reforzados con fibras" Tesis doctoral, Departamento de Construcción y tecnología Arquitectónica, UPM 1994.

(11) A. PACIOS y S.P. SHAH: en "Testing of Fiber Reinforced Concrete", (ed.D.J. Stevens et. al.), 1995, American Concrete Institute, Detroit, 189-216.

(12) Z. LI, B. MOBASHER y S.P. SHAH: Journal of the American Ceramic Society, 1991, 74, (9), 2156-2164.

\section{publicación del IETCC/CSIC}

\section{bases para el diseño solar pasivo}

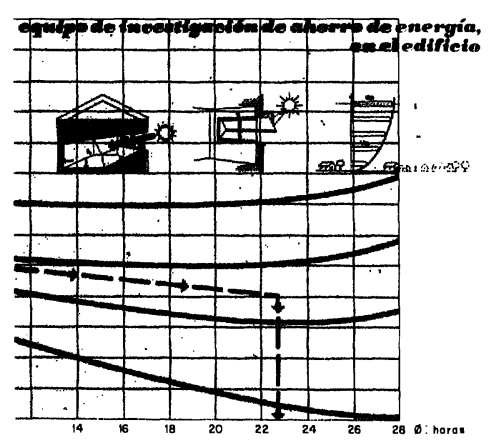

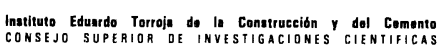

Equipo de Ahorro de Energía en el edificio

Arturo García Arroyo

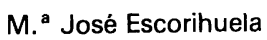

José Luis Esteban

José Miguel Frutos

Manuel Olaya

Bernardo Torroja
Dirección y coordinación:

Las dificultades de suministro y el alto coste de los productos energéticos convencionales han despertado la atención de los usuarios, ícnicos e industriales de la edificación hacia el aprovechamiento de otras fuentes alternativas de energia, principalmente la solar. Esto ha generado un rápido desarrollo industrial $y$ comercial que, en opinión de los autores de este libro, arrastran los siguientes defectos: un mimético tecnologismo respecto de los ristemas convencionales que violenta las pecistemar (baja densidad $y$ variabilidad en el tiempol, y una escasa selectividad en la aplicación de los sistemas y procedimientos pasivos dando origen a un ecumenismo arquitectónico solar, al margen de las condiciones climáticas y funcionales especificas de cada caso y lugar.

En este libro, utilizando criterios y metodologia pedagógicos, se dan los fundamentos e instrumentos teórico-prácticos necesarios para el planteamiento de todo proyecto arquitectónico solar pasivo, de acuerdo con los principios éticos y económicos de conservación y ahorro de energía. Es decir: respeto de los presupuestos bioclimáticos, búsqueda de la máxima captación y acumulación de la radiación solar, y esmero en el aislamiento térmico de los cerramientos.

Un volumen encuadernado en cartulina ibiza plastificada, a cinco colores, de $16 \times 23 \mathrm{~cm}$, compuesto de 216 páginas, 217 figuras, 87 gráficos, 19 tablas y 10 cuadros. 